\title{
Influence of Carbon, Nitrogen and Phosphorous Sources on Glucoamylase Production by Aspergillus awamori in Solid State Fermentation
}

Telma Elita Bertolin ${ }^{a^{*}}$, Willibaldo Schmidell ${ }^{\mathrm{b}}$, Alfredo E. Maiorano ${ }^{\mathrm{b}}$, Janice Casara ${ }^{\mathrm{b}}$, and Jorge A. V. Costa ${ }^{\mathrm{c}}$

a Centro de Pesquisa em Alimentação, Universidade de Passo Fundo, Caixa Postal 611, 99070-010 - Passo Fundo, RS, Brazil. Fax: +55543168455. E-mail: telma@upf.tche.br

b Instituto de Pesquisas Tecnológicas do Estado de São Paulo, São Paulo, SP, Brazil

c Departamento de Química, Fundação Universidade Federal do Rio Grande, Rio Grande, RS, Brazil

* Author for correspondence and reprint requests

Z. Naturforsch. 58c, 708-712 (2003); received November 4, 2002/March 14, 2003

It was the objective of the present study to increase the production of glucoamylase by Aspergillus awamori through solid state fermentation, using wheat bran as the main carbon source and $\left(\mathrm{NH}_{4}\right)_{2} \mathrm{SO}_{4}$, urea, $\mathrm{KH}_{2} \mathrm{PO}_{4}$, glucose, maltose and starch as additional nitrogen, phosphorus, and carbon sources. The production of glucoamylase is strongly influenced by $\mathrm{N}$ and $\mathrm{C}$ sources. A $100 \%$ increase was observed when the $\left(\mathrm{NH}_{4}\right)_{2} \mathrm{SO}_{4}$ was replaced by urea, with $\mathrm{C} / \mathrm{N}=4.8$, using maltose as the additional carbon source. $\mathrm{C} / \mathrm{P}$ ratios in a range of 5.1 to 28.7 did not induce glucoamylase production under the studied conditions.

Key words: Aspergillus awamori, Glucoamylase, Solid State Fermentation

\section{Introduction}

Solid state fermentation (SSF), a process that occurs in the absence of free water, has advantages over submerged fermentation, especially regarding the economy and simplicity of the process (Costa et al., 1998).

The industrial use of amylases has been increased, and the glucoamylase is the most produced around the world. Glucoamylase ( $\alpha$-1,4-glucan-glucohydrolases), are exoenzymes that catalyses Dglucose production from the non-reducing starch end, is synthesized in the presence of an inductor (Pandey et al., 1996). According to the most accepted mechanism of synthesis (Jacob and Monod, 1961), the regulator gene codifies the production of a repressing protein, which may bind to the operator gene and block the transcription of the structural gene. In the presence of the inductor, the repressing protein binds to it and does not interact with the operator gene, therefore allowing both the transcription process and enzymatic synthesis to occur. Thereby, the induced synthesis of the enzyme is due to its de-repression (Pazur et al., 1980).

Enzyme substrates are typical inductors with different potentials for induction, as in the case of glucoamylase synthesis induced by maltose, when compared with induction mediated by starch (Thomas et al., 1996; Chiquetto et al., 1992; Ramachandran et al., 1979). Additionally, Wang et al. (1979) report that the expression of induced enzymes may also be controlled by catabolic repression, or by repression mediated by the product that results from enzyme action (glucose, for instance). In the case of catabolic repression the cell blocks the enzyme synthesis when substrates of easier assimilation are available.

Synthesis of enzymes depends on the type of nutrients available to the organism and besides an adequate carbon source other nutrients may be equally important to the composition of the medium (Thomas et al., 1996). In fact, Chiquetto et al. (1992) and Ellaiah et al. (2002) indicated that urea was a suitable nitrogen source for glucoamylase synthesis in submerged and solid state fermentation, respectively.

Also, according to Bertolin et al. (2001) and Pandey et al. (1996), the absence of free water in solid state fermentation always results in very high concentrations of nutrients. In this fermentative process, even minor variations in the $\mathrm{C} / \mathrm{N}$ or $\mathrm{C} / \mathrm{P}$ ratios may result in quite distinct responses from the biological system, since the local concentra- 
tions are greatly superior to those of the submerged fermentation.

We studied glucoamylase production by Aspergillus awamori in solid state fermentations with different $\mathrm{C} / \mathrm{N}$ and $\mathrm{C} / \mathrm{P}$ ratios. Wheat bran was used as the main carbon source, supplemented with glucose, maltose, soluble starch or cross-link modified starch as additional carbon sources and ammonium sulfate $\left(\mathrm{NH}_{4}\right)_{2} \mathrm{SO}_{4}$ or urea as additional nitrogen sources.

\section{Material and Methods}

\section{Microorganism}

The mold Aspergillus awamori NRRL 3112 was maintained through successive transfers on potato dextrose agar (PDA). At inoculation, $1 \mathrm{ml}$ of a spore suspension $\left(10^{7}\right.$ spores $\left./ \mathrm{ml}\right)$ prepared in distilled and sterile water, was transferred to each $14 \mathrm{~g}$ medium with $63 \%$ moisture.

\section{Fermentation media}

Wheat bran containing $25 \%$ starch and $14 \%$ protein (w/w, dry mass basis) was used as the main carbon source. Each $60 \mathrm{~g}$ of this substrate was supplemented with $45 \mathrm{ml}$ of saline solution containing $\left(\mathrm{NH}_{4}\right)_{2} \mathrm{SO}_{4}(4 \mathrm{~g} / \mathrm{l}), \mathrm{KH}_{2} \mathrm{PO}_{4}(2 \mathrm{~g} / \mathrm{l}), \mathrm{MgSO}_{4}(1 \mathrm{~g} / \mathrm{l})$, $\mathrm{FeSO}_{4} \cdot 7 \mathrm{H}_{2} \mathrm{O}(6.3 \mu \mathrm{g} / \mathrm{l}), \mathrm{MnSO}_{4}(0.1 \mu \mathrm{g} / \mathrm{l})$ and $\mathrm{ZnSO}_{4}(6.2 \mu \mathrm{g} / \mathrm{l})$ (Dartora et al., 2002). This broth was set as the standard wheat bran medium (WB). The sterilization was carried out at $110^{\circ} \mathrm{C}$ for $30 \mathrm{~min}$. This medium had a $\mathrm{C} / \mathrm{N}$ ratio of 4.8 and a $\mathrm{C} / \mathrm{P}$ ratio of 25.7 . To study different $\mathrm{C} / \mathrm{N}$ and $\mathrm{C} / \mathrm{P}$ ratios, the $\mathrm{WB}$ medium was also supplemented with solutions of glucose, maltose, soluble starch (Merck, Germany) or modified cross-link starch, Starch 520 (Lorentz, São Paulo, Brazil). The quantities added were expressed in percentages of the starch amount in the standard medium [ grams of the added substance/grams of starch in the WB medium). 100]. The same procedure was used to substitute ammonium sulfate with urea and to vary the amount of ammonium sulfate, urea, and phosphate in order to study different $\mathrm{C} / \mathrm{N}$ and $\mathrm{C} / \mathrm{P}$ ratios. Afterwards, the medium was supplemented with sufficient $\mathrm{H}_{2} \mathrm{SO}_{4} 1.5 \mathrm{M}$ and $\mathrm{H}_{2} \mathrm{O}$ to adjust the medium $\mathrm{pH}$ to 4 and the moisture content to $63 \%$.
Fermentation occurred in erlenmeyers $(250 \mathrm{ml}$ capacity), each with $14 \mathrm{~g}$ culture medium, placed in incubators, without agitation, at $30^{\circ} \mathrm{C}$ and $98 \%$ relative humidity for up to $40 \mathrm{~h}$. All experiments were carried out in duplicate.

\section{Moisture}

Protocol 14004 of the Association of Official Analytical Chemists was used to assess the relative humidity of the media (A. O. A. C., 1997).

\section{Reducing sugars}

Total reducing sugars (TRS) were analyzed by hydrolyzing a known amount of sample with $1.5 \mathrm{M}$ $\mathrm{H}_{2} \mathrm{SO}_{4}$ for $60 \mathrm{~min}$, the resulting sugars, expressed as milligram of glucose per gram of dry matter $(\mathrm{mg} / \mathrm{gdm})$, were determined by the glucose-oxidase method (Barham and Trinder, 1972). Free reducing sugars (FRS) were assessed by boiling $500 \mathrm{mg}$ of medium in $20 \mathrm{ml}$ of distilled water for 5 min and determining the quantity of extracted glucose in the same way as for TRS.

\section{Glucoamylase activity}

The enzyme was extracted by adding $15 \mathrm{ml}$ of acetate buffer $(\mathrm{pH}=4.2)$ to $1 \mathrm{~g}$ of the sample and by shaking the suspension at $200 \mathrm{rpm}$ for $30 \mathrm{~min}$. Once the suspension was filtered, an adequate volume was reacted with $25 \mathrm{ml}$ of a $4 \%$ starch solution at $60{ }^{\circ} \mathrm{C}$ for $60 \mathrm{~min}$ (Schmidell and Menezes, 1986). After the hydrolysis period, the glucoamylase was heat inactivated and the glucose dosed using the glucose-oxidase method (Barham and Trinder, 1972). One activity unit (U) was defined as the amount of enzyme that in one hour released one gram of glucose under the conditions established for this experiment. The activity of the produced glucoamylase (A) was expressed in units per gram of dry matter (U/gdm).

\section{Statistical analysis}

The Tukey honest difference (HSD) test (Box et al., 1978) was used to detect differences in glucoamylase activity between the wheat bran media. All experiments were done in duplicate and the analyses (moisture, reducing sugars and glucoamylase activity) in triplicate. 


\section{Results and Discussion}

Initially the objective was to verify the effect of supplementing nitrogen and phosphorous sources in the solid state fermentation. The glucoamylase activities produced during $40 \mathrm{~h}$ of $A$. awamori growth in the media with different carbon, nitrogen and phosphorous ratios are shown in Table I, $40 \mathrm{~h}$ being chosen because after $30 \mathrm{~h}$ of fermentation glucoamylase activity was constant.

Although phosphorous is an element of great importance for the cells, the results in Table I show no significant increase, or even a decrease, in glucoamylase synthesis with the addition of phosphorous only, indicating that there was already sufficient phosphorous in the wheat bran. When ammonium sulfate only was added to wheat bran there was also no significant change, or a decrease, in enzyme activity. However, the addition of urea only, even in the small amounts necessary to reduce the $\mathrm{C} / \mathrm{N}$ ratio from 5 to 4.8 , produced a significant rise $(p$-level $=0.000183)$ in glucoamylase activity from the $13.9 \mathrm{U} / \mathrm{gdm}$ found in the unsupplemented medium to $21.5 \mathrm{U} / \mathrm{gdm}$. The beneficial effects of the addition of urea nitrogen have been reported in submerged fermentations for glucoamylase production by Aspergillus awamori and Aspergillus niger (Chiquetto et al., 1992; Swift et al., 2002). In our study, the addition of larger amounts of urea resulted in glucoamylase activity dropping to zero. Pandey et al. (1996) and Bertolin et al. (2001) also found distinct responses by the organisms involved in solid state growth systems associated with elevated local concentrations of some media components.

Costa et al. (1998) have reported that the best moisture content in a solid state fermentation depends on the nature of the substrate, the type of microorganism and the final product. Singh and Soni (2002) showed that nutrient concentration is inversely related to the amount of water in the medium. Seemingly an increase in osmotic potential can negatively affect growth and enzyme production. The $\mathrm{C} / \mathrm{N}$ ratio of 4.8 (with urea) and a $\mathrm{C} / \mathrm{P}$ ratio of 25.7 apparently provided the best osmotic balance for highest enzymatic activity among the studied conditions in our system.

The previous results also indicate that during the growth and enzyme synthesis period, the presence of free sugars was not observed, in spite of the decrease in TRS concentration. This suggests that an additional carbon source would prolong the fermentative process, thus allowing for a greater production of glucoamylase.

As mentioned before, polysaccharides may induce glucoamylase synthesis and glucose may repress it, so a series of experiments was conducted to investigate the performance of $A$. awamori in the presence of other additional carbon sources. Fig. 1 shows the relative enzyme activity after $40 \mathrm{~h}$ of fermentation and after the addition of different carbohydrates, with a constant amount of nitrogen added (equal to that of the standard medium), or maintaining constant the $\mathrm{C} / \mathrm{N}$ ratio. The relative

Table I. Glucoamylase activity (A) produced by Aspergillus awamori after $40 \mathrm{~h}$ of solid state fermentation in media with different carbon, nitrogen and phosphorous ratios.

\begin{tabular}{|c|c|c|c|}
\hline Wheat bran media & $\mathrm{C} / \mathrm{N}$ ratio & $\mathrm{C} / \mathrm{P}$ ratio & $\mathrm{A}^{*}[\mathrm{U} / \mathrm{gdm}]$ \\
\hline Without supplement (N, P) & 5.0 & 28.3 & $13.9^{\mathrm{B}, \mathrm{C}, \mathrm{D}} \pm 0.8$ \\
\hline Standard wheat bran medium & 4.8 & 25.7 & $13.7^{\mathrm{B}, \mathrm{C}, \mathrm{D}} \pm 1.1$ \\
\hline \multirow[t]{3}{*}{ Supplemented with $\left(\mathrm{NH}_{4}\right)_{2} \mathrm{SO}_{4}$} & 3.3 & 25.7 & $10.5^{\mathrm{D}} \pm 1.4$ \\
\hline & 3.1 & 25.7 & $12.5^{\mathrm{C}, \mathrm{D}} \pm 1.1$ \\
\hline & 2.9 & 25.7 & $12.2^{\mathrm{C}, \mathrm{D}} \pm 1.0$ \\
\hline \multirow[t]{3}{*}{ Supplemented with urea } & 4.8 & 25.7 & $21.5^{\mathrm{A}} \pm 1.5$ \\
\hline & 3.1 & 25.7 & $16.9^{\mathrm{B}} \pm 1.8$ \\
\hline & 1.0 & 25.7 & $0.0^{\mathrm{E}} \pm 0.0$ \\
\hline \multirow{3}{*}{ Supplemented with $\mathrm{KH}_{2} \mathrm{PO}_{4} * *$} & 4.8 & 20.1 & $15.5^{\mathrm{B}, \mathrm{C}} \pm 1.1$ \\
\hline & 4.8 & 14.3 & $14.3^{\mathrm{B}, \mathrm{C}} \pm 2.3$ \\
\hline & 4.8 & 5.1 & $13.3^{\mathrm{C}, \mathrm{D}} \pm 1.8$ \\
\hline
\end{tabular}

* Mean \pm standard deviation.

** Using $\left(\mathrm{NH}_{4}\right)_{2} \mathrm{SO}_{4}$ as nitrogen source.

A,B,C,D,E Enzymatic activities with the same exponent do not differ significantly $(\mathrm{p}<0.05)$ in agreement with the Tukey test. 


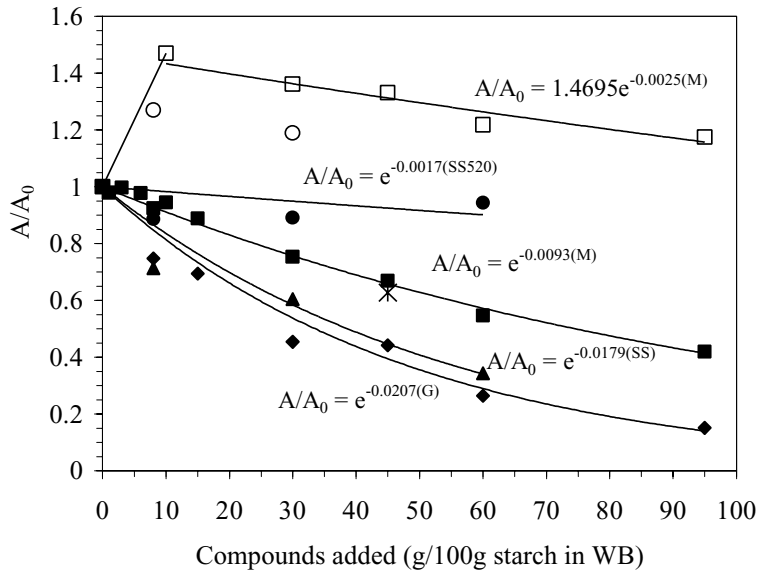

Fig. 1. Relative enzymatic activity $(\mathrm{A} / \mathrm{Ao}=$ glucoamylase activity in the studied medium/glucoamylase activity of the standard medium) associated with the addition of various carbon sources, after $40 \mathrm{~h}$ of fermentation, maintaining fixed the amount of $\left(\mathrm{NH}_{4}\right)_{2} \mathrm{SO}_{4}$ added, or maintaining fixed the ratio $\mathrm{C} / \mathrm{N}=4.8$ by the addition of $\left(\mathrm{NH}_{4}\right)_{2} \mathrm{SO}_{4}$ (indicated by "suf") or urea (indicated by

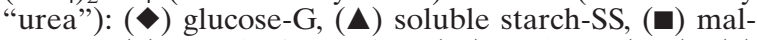
tose-M, (•) starch 520-SS520, (*) maltose (sulf), (o) starch 520 (urea), ( $\square$ ) maltose-M (urea). Curves plotted according to the indicated equations.

enzymatic activity $\left(\mathrm{A} / \mathrm{A}_{0}\right)$ was defined as the relationship between the glucoamylase activity in the studied medium (A) and that of the standard me$\operatorname{dium}\left(\mathrm{A}_{0}\right)$.

Fig. 1 indicates that the addition of distinct carbon sources in the presence of ammonium sulfate does not stimulate the synthesis of glucoamylase by $A$. awamori. In contrast, there was a reduction in enzyme synthesis as the additions were increased. Enzyme activity without carbon addition $\left(\mathrm{A}_{0}\right)$ reached $13.7 \mathrm{U} / \mathrm{gdm}$, as observed in Table I.

Apparently the addition of glucose appeared to strongly repress the enzyme synthesis, and the exponential model fit to the experimental data had a negative exponent (- 0.0207). A similar response was obtained when soluble starch was added to the medium (exponent $=-0.0179$ ). The addition of maltose caused a minor repressive effect (exponent $=-0.0093$ ) and the use of Starch 520 had little influence (exponent $=-0.0017$ ) on glucoamylase synthesis.

Fig. 1 also shows the data obtained using urea as a nitrogen source and varying the amount of maltose, while maintaining the $\mathrm{C} / \mathrm{N}(4.8)$ and the $\mathrm{C} / \mathrm{P}$ (25.7) ratios fixed. The experiments without the addition of maltose, but using urea, increased the activity to above $20 \mathrm{U} / \mathrm{gdm}$ (Table I). Small additions of maltose (about $10 \%$ of the starch present in the WB medium) allowed significantly higher activities to occur $\left(\mathrm{A} / \mathrm{A}_{0}=1.48\right)$. However, higher values of maltose reduced the activity of glucoamylase, although the exponent of the adjusted model was smaller than that obtained with maltose and ammonium sulfate (similar observation was obtained in the case of Starch 520). This additional fact emphasizes the importance of having suitable sources of distinct nutrients to obtain good performance in such fermentations.

Fig. 2 presents the time course of the free glucose concentration for the experiments in which distinct saccharides were added up to $60 \%$ of the starch present in the WB medium. In all the experiments the amount of free glucose was greater in the supplemented media, which may affect enzyme synthesis. Free glucose was not so high in the run with addition of Starch 520 whose chemical structure may limit its hydrolysis. In contrast, maltose had less negative effect in enzyme production than soluble starch, probably because maltose is a better inducer than soluble starch, as already reported (Chiquetto et al., 1992; Ramachandran et al., 1979). Furthermore, the accumulation of glucose tended to be lower in the experiments with addition of maltose and urea, which may be an additional factor for better performance in glucoamylase production of this me-

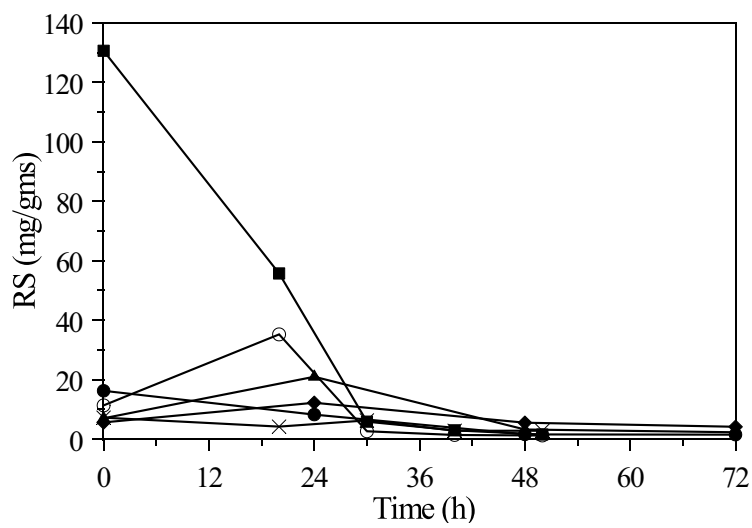

Fig. 2. Time course of free reducing sugars (RS), represented as glucose, for experiments supplemented with carbohydrates (addition of $60 \%$ relative to the starch in the WB medium): (ם) glucose, (o) maltose and $\left(\mathrm{NH}_{4}\right)_{2} \mathrm{SO}_{4},(\bullet)$ maltose and urea, ( $\left.\boldsymbol{\Delta}\right)$ soluble starch, (•) starch $520,(\times)$ standard wheat bran medium. 
dia. It must be emphasized that this better performance was not due to a different cellular growth, since the growth curves obtained for the assays with additional $60 \%$ of maltose and adding sulfate or urea were practically coincident (data not shown).
Association of Official Analytical Chemists A. O. A. C. (1997), Official Methods of Analysis. 16th ed., Arlington VA., USA.

Barham D. and Trinder P. (1972), An improved colour reagent for the determination of blood glucose by the oxidase system. Analyst. 97, 142-145.

Bertolin T. E., Costa J. A. V., and Pasquali G. D. (2001), Glucoamylase production in batch and fed-batch solid state fermentation: effect of maltose and starch addition. J. Microbiol. Biotechnol. 11, 13-16.

Box G. E. P., Hunter W. G., and Hunter J. S. (1978), Statistics for Experimenters: An Introduction to Design, Data Analysis, and Model Building. Wiley \& Sons, New York, USA.

Chiquetto M. L., Facciotti M. C. R., Kilikian B. V., and Schmidell W. (1992), Influence of carbon and nitrogen sources on glucoamylase production by Aspergillus in batch process. Biotechnol. Lett. 14, 465-470.

Costa J. A. V., Alegre R. M., and Hasan S. D. M. (1998), Packing density and thermal conductivity determination for rice bran solid-state fermentation. Biotechnol. Tech. 12, 747-750.

Dartora A., Bertolin T. E., Bilibio D., Silveira M. M., and Costa J. A. V. (2002), Evaluation of filamentous fungi and inducers for the production of endo-polygalacturonase by solid state fermentation. Z. Naturforsch. 57c, 666-670.

Ellaiah P., Adinarayana K., Bhavani Y., Padmaja P., and Srinivasulu B. (2002), Optimization of process parameters for glucoamylase production under solid state fermentation by a newly isolated Aspergillus species. Process Biochem. 38, 615-620.

Jacob F. and Monod J. (1961), Genetic regulatory mechanisms in the synthesis of protein. J. Mol. Biol. 318 356.
Pandey A., Selvakumar P., and Ashakumary L. (1996), Performance of a column bioreactor for glucoamylase synthesis by Aspergillus niger in SSF. Process Biochem. 31, 43-46.

Pazur J. H., Tominaga Y., Forseberg L. S., and Simpson D. L. (1980), Glucoenzymes: an unusual type of glucoprotein structure for a glucoamylase. Carbohydrate Res. 84, 103-114.

Ramachandran N., Sreekantiah K. R., and Murthy V. S. (1979), Influence of media composition on the production of alpha-amylase and amyloglucosidase by a strain of Aspergillus niger. Starch/Stärke 31, 134138.

Schmidell W. and Menezes J. R. G. (1986), Influência da glicose na determinação da atividade da amiloglicosidase. Rev. Microbiol. 17, 194-200.

Singh H. and Soni S. K. (2002), Production of starch-gel digesting amyloglucosidase by Aspergillus oryzae HS3 in solid state fermentation. Process Biochem. 37, $453-459$.

Swift R. J., Karandikar A., Griffen A. M., Punt P. J., van den Hondel C. A. M. J. J., Robson G. D., Trinci A. P. J., and Wiebe M. G. (2002), The effect of organic nitrogen sources on recombinant glucoamylase production by Aspergillus niger in chemostat culture. Fungal Genet. Biol. 31, 125-133.

Thomas K. C., Hynes S. H., and Ingledew W. M. (1996), Effect of nitrogen limitation on synthesis of enzymes in Saccharomyces cerevisiae during fermentation of high concentration of carboydrates. Biotechnol. Lett. 18, 1165-1168.

Wang D. I. C., Cooney C. L., Demain A. L., Dunnil P., Humphrey A. E., and Lilly M. D. (1979), Ferment. Enzyme Technol. Wiley \& Sons, New York, USA. 